\title{
Public Accounting Firm Reputation and Status Incentives for Employee Benefit Plan Audit Quality
}

\begin{abstract}
There is a relatively large stream of empirical literature on the peer review process providing evidence that peer review deficiencies in the financial accounting context are associated with competition and experience incentives. Given that most prior studies use public company data no longer under subject to peer review, this study attempts to address whether these findings are relevant in a subsector which retained peer review regulation: employee benefit plan audits. Building upon this stream of prior literature and using reputation theory and institutional theory, this study tests whether reputation and status of public accounting firms are associated with peer review deficiencies and auditor switches. Analyzing a sample of New York public accounting firms, this study provides evidence that both the reputation and the relative status of the peer reviewer is the most important determinant of peer review deficiencies. However, neither of these determinants is associated with changes in client mix. This study fills a call for additional research into the determinants of audit quality in the regulated employee benefit plan audit industry. While recent changes in the regulation of the employee benefit plan audit sector may enhance audit quality, the public interest will only be fully protected through greater limitations placed on public accounting firm participation in this market or independent regulation of this audit sector.
\end{abstract}

Keywords: Auditor Reputation; Employee Benefit Plan Audits; Peer Review 


\section{INTRODUCTION}

Peer review of public accounting firms has undergone significant changes over the past twenty years. Prior to the passage of the Sarbanes-Oxley Act, a self-regulation regime existed for all types of audit engagements. However, there was a breakdown in this regime due to concerns that this system was predominantly ceremonial in nature and identified very few audit failures (Fogarty 1996). As early as 1978, SEC Chief Accountant John Burton declared that the current peer review program "is likely to be seen as a process of mutual backscratching” (Board 2002). Despite these warnings from academia and regulators, an unfortunate implication of this reality was that public accounting firms had less stringent quality control structures at that time, mostly clearly evidence in the failure of Arthur Andersen and particularly due to their contribution to Enron's downfall (Board 2002). In response, the regulation of public company financial statement audits was no longer performed using peer public accounting firms but by professional regulators employed by the Public Company Accounting Oversight Board.

Nevertheless, there are several segments of the external assurance market in the United States still regulated using peer review. While the largest of these is the audit of privately held companies, regulated audits of organizations receiving governmental funding and audits of organizations operating an employee benefit plan are also subject to peer review. In these two specialized audit markets, auditors face relatively high barriers to entry via mandated continuing professional education hours within the specialized industry due in part to the significant difference in nature of information under audit from corporate financial statements. Both types of audits focus upon identifying whether information complies with U.S. governmental regulations (including those of the Department of Labor for employee benefit plans). 
Specifically focusing on role of external audits in the U.S. employee benefit plan industry, very little is known in the academic literature. Cullinan (1997) notes that there is often ample opportunity for service bundling of both the financial statement audit and the employment benefit plan audit. This study also notes that many of the determinants of audit fees (e.g. size; complexity) are also associated with changes in audit fees in the multi-employer benefit plan market. Cullinan (1998) additionally provides evidence that smaller public accounting firms have an opportunity to gain market share in this industry sector unlike that of U.S. publicly traded companies as he finds no association between either auditor brand name or industry specialization and audit fees. Finally, Porter (2018) describes the nature of this industry and notes that little is known about the determinants of audit quality in this industry. Unlike financial statement audits, stakeholders typically only identify compliance issues for employee benefit plans when major problems arise (e.g. peer review deficiency). As a result, this study considers the following research question: is there an association between the reputation incentive of a public accounting firm and peer review report outcomes for employee benefit plan audits?

Building upon prior peer review research (e.g. Hilary and Lennox 2005; Anantharaman 2012), this study analyzes the U.S. single employer employee benefit plan industry to identify potential determinants of deficiencies in audit firm peer review reports. Two primary attributes make this a worthwhile setting for this research question. First, employee benefit plans are a "must select" industry under the AICPA peer review program (AICPA 2015). As a result, both the public accounting firm providing benefit plan audit services and their peer reviewer will scrutinize the documentation and quality control structures surrounding these engagements. Second, given both the high barrier to entry and the strong potential for reputation building in this industry, deficient audits likely occur more frequently than in financial statement audits. 
Analyzing a dataset of public accounting firms headquartered in the state of New York, this study provides evidence consistent with both prior research in peer review as well as reputational incentives consistent with signaling theory. First, public accounting firms that signal their reputation in the employee benefit plan on their firm's website are associated with a lower likelihood of receiving a peer review deficiency. Additionally, firms which do not have a prominent status in the industry (i.e. do not serve on either the state or AICPA employee benefit plan committee) are more likely to receive a peer review deficiency when they select a peer reviewer with a prominent reputation in the industry.

Analyzing auditor changes, this study also provides evidence that it may be advantageous for a public accounting firm to undergo a more stringent peer review. Consistent with evidence from peer reviews of financial statement audits (e.g. Lennox and Pittman 2010), public accounting firms receiving a peer review deficiency are not strongly penalized in terms of losing client engagements. More importantly, for public accounting firms with a prominent industry reputation, these firms gain valuable insight into their own processes and there is evidence these forms may gain additional client market share when they have a peer review from a firm with a prominent industry reputation.

By analyzing a current gap in the peer review literature, this study provides evidence that reputation and status incentives for public accounting firms are strongly associated with peer review outcomes in the employee benefit plan industry. This finding is consistent with analysis by the U.S. Department of Labor (DOL 2015) that public accounting firms which perform very few employee benefit plan audits are more likely to have deficiencies and, from the findings in this study, are less likely to signal their industry reputation and status. 
The remainder of the paper is organized as follows. Section 2 describes the background literature on peer review and employee benefit plan audits. Section 3 argues for the hypothesized relationship between audit firm reputation and status and peer review. Section 4 describes the empirical models. Section 5 provides the empirical results. Section 6 concludes the paper.

\section{LITERATURE REVIEW}

\section{Nature of the Employee Benefit Plan Industry}

In the United States, both public sector and private sector employees are often covered by employee benefit plans as part of a comprehensive set of pecuniary benefits. Two common forms of employee benefit plans are known as "defined benefit plans" and "defined contribution plans" (Bodie et al. 1988). For a defined benefit plan, the employer manages investments and guarantees a specified payout to employees upon retirement. Unlike defined benefit plans, "defined contribution" plans give employees control over investing decisions but also shifts responsibility for accruing sufficient retirement earnings into employees' hands. Despite the distinction in the nature of employee benefit plans, companies have similar compliance regulations for both types of plans in the United States. Under the Employee Retirement Income Security Act of 1974 ("ERISA"), companies are required to annually report plan information and its financial operations on IRS Form 5500 to the U.S. Department of Labor and the Internal Revenue Service. Porter (2018) provides additional description of the current regulatory environment for U.S. employee benefit plans.

In the academic literature, the majority of prior research focuses upon market factors associated with changes between types of employee benefit plans (e.g. Beaudoin et al. 2010; Choy et al. 2014), valuation characteristics of pension plans (e.g. Dhaliwal 1986; Francis and 
Reiter 1987; Asthana 1999), or accounting changes for pension plans (e.g. Amir and Ziv 1997; D'Souza et al. 2000). One notable exception is Anantharaman (2017), which provides evidence that external auditors with greater monitoring incentives are associated with increased manipulation through actuarial assumptions underlying employee benefit plans. An implication of this study is that more reputable external auditors constrain accounting manipulations to only operational areas outside of their direct ability to enforce change (i.e. actuarial assumptions).

Focusing on the literature studying employee benefit plan audits, there are both similarities and distinctions from the financial statement audit market. Similar to financial statement audits, there is evidence of an association between preparer operational characteristics (e.g. size; complexity) and audit fees (Cullinan 1997). However, prior research is unclear whether auditor reputation is associated with changes in audit fees. In the U.S. context, Cullinan (1997) and Cullinan (1998) found no evidence of an auditor brand name or industry specialist association with audit fees. More recently, Arnold et al. (2016) provide evidence on small employee benefit plans in Australia that industry specialists charge lower audit fees. Figure 1 below provides an author-derived summary of these distinctions.

\begin{tabular}{|l|l|l|}
\hline \multirow{3}{*}{ Aim } & Financial Statement & Employee Benefit \\
\cline { 2 - 3 } & $\begin{array}{l}\text { Endit } \\
\text { fairly presented in accordance with } \\
\text { GAAP. }\end{array}$ & $\begin{array}{l}\frac{\text { Ensure compliance with }}{\text { Plan Audit }} \\
\text { regulations (e.g. U.S. Department } \\
\text { of Labor). }\end{array}$ \\
\hline Parket Makeup & $\begin{array}{l}\text { Big 4 dominance } \\
\text { Greater market disaggregation }\end{array}$ \\
\hline Role of Expertise & $\begin{array}{l}\text { Fee highly associated with } \\
\text { company size }\end{array}$ & $\begin{array}{l}\text { Fee associated with benefit plan } \\
\text { type and scope of audit (e.g. } \\
\text { limited vs. full scope) }\end{array}$ \\
\hline
\end{tabular}

Figure 1 - Distinctions between Financial Statement and Employment Benefit Plan Audits 
This stream of literature suggests, echoing Porter (2018), that there very little understanding of the nature and operating practices of external auditors in the employee benefit plan market. This study attempts to increase this understanding by evaluating one form of audit outcome: peer review report results.

\section{Role of Peer Review in Regulating External Audits}

In the United States, peer review became increasingly required of public accounting firm throughout the second half of the $20^{\text {th }}$ century under the auspices of the largest professional organization of certified public accountants (AICPA). Under peer review, the identified independent external public accounting firm (hereafter "independent evaluator") reviews documentation from the public accounting firm to ensure that it is compliant with generally accepted auditing standards ("GAAS") and/or quality control standards (AICPA 2015). At the completion of the peer review, a professional opinion is issued with three possible outcomes: (1) pass (similar to an unqualified opinion in a financial statement audit), (2) pass with deficiencies (similar to a qualified opinion in a financial statement audit), and (3) fail (similar to an adverse opinion in a financial statement audit). Unlike the normal circumstances surrounding PCAOB inspection report findings, quality control findings are publicly disclosed with a description of the nature of each deficiency (Hilary and Lennox 2005).

Per AICPA (2015), two primary types of peer reviews exist: system reviews and engagement reviews. Under a system review, the independent evaluator examines whether the public accounting firm has sufficient policies and procedures in place to ensure that assurance service engagements have sufficient documented evidence to support the public accounting firm's professional conclusion. In addition, the independent evaluator selects a sample of engagements to identify whether sufficient documented evidence exists to ensure that the public 
accounting firm complied with GAAS. If the public accounting firm performs professional services in certain specialized areas, such as employee benefit plans, the independent evaluator must select employee benefit plan engagements as part of their peer review and undergo a system review. For the second type of peer review, an engagement review, only engagement working papers are evaluated and not the public accounting firm's system of quality control.

However, peer review has been wrought with numerous concerns that ultimately led to a change to the PCAOB inspection regulatory regime for audits of publicly traded companies. First, the peer review regulatory regime is inherently constructive and non-punitive in nature (e.g. Fogarty 1996). In contrast with the PCAOB inspection process which diverts auditor attention from professional judgement toward an unhealthy obsession over audit documentation (Westermann et al. 2018), the peer review process typically lacks a significant sanctioning process for egregious deficiencies. Without moral hazard concerns, public accounting firms may not be as concerned with the outcome of a peer review. Second, there is concern that the public accounting firm may select an independent evaluator that may not closely scrutinize their work. As quoted in Hilary and Lennox (2005), the Public Oversight Board (Board 2002) stated that "mutual backscratching" is a commonly held perception of the peer review process. Finally, it is possible that the public accounting firm may "game" the peer review process by providing its highest quality example engagements to peer reviewers. Russell and Armitage (2006) surveyed a random set of 500 AICPA member public accounting firms and found that roughly $17 \%$ of survey respondents admitted that their independent evaluator allowed them to self-select sample engagements for compliance with professional standards. DeFond (2010) reviews arguments for the relative tradeoffs of the two regulatory regimes and Löhlein (2016) reviews the literature on the relative incentives surrounding auditor regulation. 
Despite these significant concerns with the peer review process, there are several reasons why the peer review process is a worthwhile setting for studying audit outcomes in the employee benefit plan industry. First, as noted in Porter (2018), this industry is highly complex and has little overlap with financial statement audits. As a result, it remains an empirical question whether prior research on peer review is applicable in the "must select" employee benefit plan industry. Second, the employee benefit plan market allows for smaller public accounting firms to develop market share (Cullinan 1998). While that is the case, quality control structures vary significant based upon size according to professional standards (PCAOB QC 20.04; AICPA QC 10.05). Since the nature of employee benefit plan audits are compliance audits, deficiencies in the peer review report may be viewed more negatively by their clients relative to financial statement audits involving professional judgment.

\section{HYPOTHESIS DEVELOPMENT}

\section{Role of Industry Expertise in Employee Benefit Plan Audits}

Within the behavioral auditing literature, there is a well-developed stream of literature connecting auditor expertise and performance (e.g. Libby and Luft 1993). One implication of these earlier studies is that individual auditors are most likely to improve performance as they develop tailored task-specific knowledge. As mentioned earlier, the employee benefit plan industry is highly complex and its compliance-oriented nature requires auditors to develop knowledge structures that are less likely to be transferrable to other types of audit engagements. Moroney (2007) provides evidence that employee benefit plan auditors (referred to as "superannuation" in the Australian context) with greater industry experience analyze industry- 
specific information more efficiently and effectively than those without this industry experience. Moroney and Carey (2011) build upon this study and identify that industry-specific experience (e.g. auditing employee benefit plans) is more important than task-based experience (e.g. auditing investments) when evaluating auditor performance. Finally, Moroney and Simnett (2009) provide evidence that auditors with employee benefit plan have a greater ability to identify business risks related to their industry relative to a non-specialist.

Given this understanding, the archival auditing literature has used industry specialization as a proxy for expertise (e.g. Francis 2011; Knechel et al. 2012). Given the compliance-oriented nature of employee benefit plan audits, it is feasible that many smaller firms can develop expertise since many compliance tasks are performed irrespective of plan size (Cullinan 1998). Yet, within the employee benefit plan industry, Tysiac (2015) provides anecdotal evidence that small public accounting firms take on employee benefit plan audits in order to retain clients' alternative revenue streams from other professional services (e.g. tax preparation). This suggests that audit quality in the employee benefit plan industry may not be driven primarily by auditing the largest proportion of clients (i.e. market share) but by performing a sufficient number of client engagements to develop sufficient industry knowledge (i.e. client count measures).

Consistent with this expectation, the United States Department of Labor performed their most recent periodic compliance audit of individual employee benefit plan audits during 2014 to ensure compliance with generally accepted auditing standards (DOL 2015). As part of this study, they identify a monotonic inverse relationship between the number of clients and audit quality (see Porter 2018 for additional discussion). Given this evidence, it is expected that employee benefit plan auditors with greater experience will be less likely to receive a deficient peer review as hypothesized below: 


\section{H1: Public accounting firms performing a larger number of peer review engagements (i.e. more "experienced" firms) will be less likely to receive a deficient peer review.}

\section{Role of Industry Reputation in Employee Benefit Plan Audits}

Unlike many other industry sectors, the public accounting industry has a relatively short history of using advertising or branding as a signal of expertise. Historically, public accounting firms were banned from advertising and, even when allowed to do so, many chose not to given prior social norms (e.g. Finn et al. 1988). Nevertheless, it is commonly understood that advertising is one of the best ways for companies to gain new clients. Building upon signaling theory, Weigelt and Camerer (1988) synthesize the literature on corporate reputation building and identify that companies can use advertising spending as a signal to customers that the company is providing them with a high quality product.

In the current digital world, online presence has become increasingly important for businesses. Despite the relative sophistication of social media and digital marketing, Ryan (2016) argues that a company's website is their "most valuable piece of digital real estate". Ryan (2016) additionally claims that personalizing a company's website is crucial for increasing marketing effectiveness. Within the accounting literature, Suddaby et al. (2015) analyze Big 4 websites and social media platforms and provide evidence that digital content related to expert knowledge is primarily organized along industries (e.g. manufacturing; financial services). These authors argue that, as a form of traditional media, websites are primarily designed to curate firm-specific reputation while social media allows individual accountants to enhance the firm's reputation indirectly. 
One key area where employee benefit plan auditors may signal their reputation is through their firm website. While it is generally accepted that public accounting firms organize their professional practice along industry lines (e.g. Carson 2009), potential clients may not know whether an individual public accounting firm has expertise in a specific industry. One way of quickly communicating that information to prospective clients is on their firm website (O'Bannon 2016). While this is relatively inexpensive advertising, simply listing on their firm website that they perform employee benefit plan audits may signal that they provide a high quality audit as hypothesized below.

\section{H2: Public accounting firms explicitly listing that they perform employee benefit plan audits on their firm website (i.e. more "reputable" firms) will be less likely to receive a deficient peer review.}

\section{Role of Industry Status in Employee Benefit Plan Audits}

Similar to reputation, status is a construct which serves as a signal for product quality when actual quality is unobservable (Podolny 1994). As this research describes, status refers to the relative market position or prominence of different companies, particularly in terms of which companies do business with one another. In the financial statement audit market, one example of a status symbol is membership in the Center for Audit Quality ("CAQ") (Lampe et al. 2016). While there are over 700 public accounting firms affiliated with the employee benefit plan audit market, governing board membership "comprises leaders from the public company auditing firms, the American Institute of CPAs ("AICPA") and the investor and issuer communities" (CAQ 2018). In practice, only audit firm leaders from the Big 4 as well as the next four largest international public accounting represent the public company auditing firms on the governing 
board. This suggests that these firms have the greatest influence in this industry, particularly in an era of decreased AICPA influence (Sellers et al. 2015; Lampe et al. 2016).

In the employee benefit plan audit market, there is no similar organization to the CAQ. However, both the AICPA and a majority of the state CPA societies have professional committees for employee benefit plan related issues. These committees allow representatives to arguably enhance their professional network through increased spreading of new ideas but also social status via the mechanism of "weak ties" (Granovetter 1983). Additional benefits include potential client referrals and increased visibility in the professional community (Harper and Allen 1997). More formally, these committees provide an opportunity for prosocial behavior but also allow for an enhanced public image in the process (e.g. Bénabou and Tirole 2006; Ariely et al. 2009; Carpenter and Myers 2010).

Beyond these benefits, it is possible that the increased status from membership in a professional committee may enhance their audit quality, whether directly through greater knowledge of high quality audit procedures learned from other experts or indirectly through receiving a less stringent peer review by becoming part of the social order (Pentland and Carlile 1996; Power 2003). As a result, the relative status of the employee benefit plan auditor and the independent evaluator may affect the outcome of the peer review process. In particular, a mismatch where the independent evaluator is a member of a professional committee ("high status") and the employee benefit plan auditor is not ("low status") may provide a greater likelihood that deficiencies will be identified during the peer review since the independent evaluator may believe that protecting audit quality in the industry is especially important.

\section{H3: Public accounting firms with a relative mismatch in social status (i.e. lower "status" firms) with their independent evaluator will be more likely to receive a deficient peer review.}




\section{Outcome Implications of the Peer Review Reporting Process}

Prior literature on the peer review process identifies changes in client count as a key measure of the impact that a peer review report has on the market. Hilary and Lennox (2005) provide evidence that peer review firms which receive a passing peer review report gain clients while firms receiving a deficient peer review lose clients. Casterella et al. (2009) attribute receiving peer review findings to greater client complexity, lower perceived independence, and lower experience levels. Interesting, Lennox and Pittman (2010) provide evidence that the lowest quality public accounting firms have incentives to exit the financial statement audit industry upon receiving a failing peer review outcome.

Within the employee benefit plan industry, there are relatively sizable sanctioning mechanisms for employee benefit plan preparers of up to $\$ 50,000$ for deficient regulatory filing (DOL 2015). While an employee benefit plan auditor would not be directly responsible for these sanctions, this suggests that audit quality is highly important in this industry and that deficient audits could spell an increased likelihood of preparers receiving sanctions themselves. As a result, it is expected that the incentives for improved peer review reporting hypothesized earlier would likely be similar to those found in the financial accounting setting:

\section{H4: Public accounting firms receiving a deficiency will lose a greater proportion of their clients in the year following a peer review than those with a passing peer review.}

\section{RESEARCH METHODS}

\section{Empirical Models}

In order to test the first three hypotheses, a logistic regression in equation one below is used to predict the relative effect of various potential determinants of peer review deficiencies: 
Prob. $($ Deficiency $=1)=b_{0}+b_{1} *$ LogAuditCount $+b_{2} * E B P \_$Industry_Website

$+b_{3}{ }^{*}$ EBPCommitteeMember $+b_{4} *$ ReviewerEBPCommitteeMember

$+b_{5}{ }^{*}$ BothEBPCommitteeMember $+b_{6} *$ NYPeerReviewer $+b_{7} *$ AlsoReviewsEBP

$+b_{8}{ }^{*}$ LogPartners $+b_{9} *$ Human_Capital_Leverage_Ratio $+b_{10} *$ Zero_Issuers

$+b_{11}{ }^{*}$ SoleProprietorship $+b_{12}{ }^{*}$ SingleOffice + Year Dummies $+\mathcal{E}$

Within the equation above, the number of employee benefit plans audited by the public accounting firm (LogAuditCount) provides them with increased opportunities for experience in performing benefit plan audits. When they perform more audits, while there are increased opportunities for deficient work, they likely gain a greater advantage from a better-developed quality control structure. Regarding reputation, the presence of employee benefit plans as a client service on the public accounting firm's website (EBP_Industry_Website) serves as a signal of a greater commitment to this niche industry. As a result, they are more likely to build a reputation in the industry and have improved audit quality. Three variables measure the relative status of the public accounting firm and their independent evaluator public accounting firm using the public available listing of employee benefit plan committee members for both the AICPA and the NY State Society of CPAs (see next section for sample description). To measure status, an indicator variable is used for whether a firm employee serves on either committee (EBPCommitteeMember), an employee from the independent evaluator serves on either committee (ReviewerEBPCommitteeMember), or both members of the pairing have committee member (BothEBPCommitteeMembers). Appendix A provides additional detailed description of each of these variables.

Among the control variables, prior research (e.g. Hilary and Lennox 2005; Anantharaman 2012) suggests that geographic proximity with the independent evaluator is associated with more stringent peer reviews (NYPeerReviewer). Anantharaman (2012) also provides evidence that firms performing peer reviews are less likely to receive peer review deficiencies. Controlling for 
size as well as known determinants of PCAOB inspection findings (Bills et al. 2015), the number of audit partners is included within this model. For similar reasons, both the human capital leverage ratio (ratio of CPAs to partners) and whether the firm performs public company audits is included in the model (Kang et al. 2014). Finally, the structure of the public accounting firm as either a sole proprietorship or a single office firm is included to control for less complex firm quality control structures (Kang et al. 2014).

Equation 2 tests whether public accounting firms that receive a deficiency have changes in their audit client mix. This empirical design is consistent with this stream of prior research but with one important modification in this context. In the financial accounting setting, there is a single audit-client relationship that makes counting client changes relatively uncomplicated. In the employee benefit plan context, one client may run a single employee benefit plan or they may run a large number of benefit plans for their employees. In order to disentangle whether a change in client count is due to an employer discontinuing a benefit plan or due to an audit change, a distinction is made between these changes outside of the public accounting firm's control and "organic" changes due to the client must first be identified between Form 5500 databases.

Therefore, while the general structure of client changes follows prior literature (e.g. Hilary and Lennox; Anantharaman 2012), client changes in this setting are only those which are related to an "organic" change (as opposed to a plan closure under the purview of the company's management). Each of the three dependent variables below (Log Chg in EBP Clients; \% Chg in EBP clients; Sign (Chg in EBP clients)) otherwise follow prior research (Hilary and Lennox 2005; Anantharaman 2012). Otherwise, the only other change based on these two studies is a 
control for the prior year's audit client count to control for the possibility that firms with a larger client count may be more apt to have changes in client count.

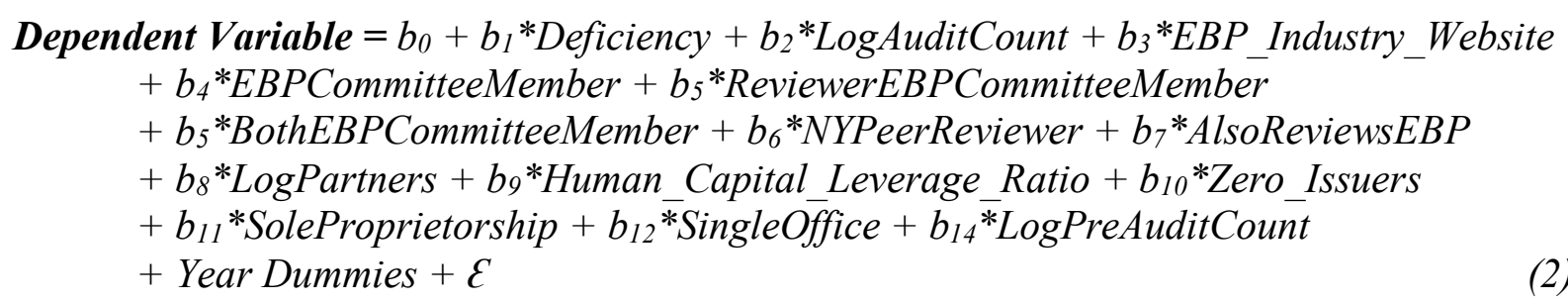

\section{Sample and Data}

In order to test these hypotheses regarding peer review, this study starts with a population of public accounting firms headquartered in New York State for several reasons: First, while AICPA member firms were required to undergo peer review, mandatory peer review is a relatively new requirement in New York. Reasons for the lack of such a requirement until 2012 mirror the common perceptions in the literature including the perception that peer review would not catch high-profile fraud cases such as Enron (Grumet 2005). As a result, public accounting firms may pay closer attention to their quality control structures given a contemporaneous change in their state regulatory environment, especially given the multi-billion dollar Madoff fraud in New York City that may have been prevented with an appropriate peer review (Kranacher 2012). Second, many of the large accounting organizations have significant operations in New York State, including the AICPA, the Public Company Accounting Oversight Board, and the Institute of Management Accountants. For public accounting firms desiring to enhance their audit quality, ample opportunities exist to network with high profile professionals. Third, given that most of the Big 4 public accounting firms are headquartered in New York and the international prominence of New York City, there may be a greater incentive for smaller public accounting firms to invest in audit quality to remain competitive larger public accounting 
firms. Finally, focusing on a single state allows for simpler identification of professional interconnectedness and reputational measures used in this study.

Consistent with the practice environment described in Hilary and Lennox (2005), the AICPA only retains the most recent peer review report online for accounting firms which are members of the AICPA Employee Benefit Plan Quality Center. For each firm, up to three files are posted online. Peer review reports were hand collected as of February 2018 based upon a publicly available list of public accounting retaining membership within the AICPA Employee Benefit Plan Audit Quality Center as of December 2017. For the peer review report, this identifies the independent evaluator firm name, the public accounting firm's peer review report grade, and along with a description of any identified deficiencies. For the acceptance letter, this indicates the remedial conditions agreed upon by the public accounting firm if any deficiencies are identified in the peer review. For the completion letter, this indicates the verification of the completion of the peer review from the certifying body (AICPA or a state CPA society). For the purpose of this study, all necessary data about each public accounting firm was hand coded from the peer review report.

Four primary data sources are used in this study. First, as described above, peer review reports for each public accounting firm headquartered in New York State that is a member of the AICPA Employee Benefit Audit Quality Center. Along with this data, a listing of all employee benefit plan regulatory submissions (Form 5500) is collected for each calendar year from 20102016 from a public database hosted by the U.S. Department of Labor. Within Schedule H of Form 5500, the name of the accounting firm that evaluates the benefit plan is listed along with an Employer Identification Number (EIN) that serves as the primary identifier with the U.S. Internal Revenue Service. Firm-specific client counts are calculated using the primary EIN (i.e. largest 
quantity) associated with each public accounting firm. Third, data about the reputation and status of public accounting firms were hand collected from either public accounting firm websites or from state or national CPA society websites in May 2018. Finally, Audit Analytics data is used to identify whether each public accounting firm has any publicly traded clients. This information is crosschecked against the PCAOB's public accounting firm lookup, which identifies whether a public accounting firms audits a public issuer and is subject to their regulatory regime.

\section{Univariate Statistics and Correlations}

Table 1 provides a detailed description of the sample composition for this study. Annually inspected PCAOB firms are dropped from the sample since they typically have more highly sophisticated quality control structures than smaller public accounting firms and compete for employee benefit plan clients based upon brand name alongside reputation and status. Public accounting firms that were subsequently acquired by another accounting firm or were otherwise missing data were also dropped from the sample. As noted in panel B of table 1, roughly 80 percent of public accounting firms received passing peer review reports and this remains relatively consistent in the final samples used to test the hypotheses of this study.

Table 2 provides univariate statistics for the variables of interest in this study. Among the sample firms, slightly more than 15 percent of public accounting firms receive a deficiency (i.e. pass with deficiencies or fail"') on the most recent peer report hand collected during February 2018. Unsurprisingly given the makeup of these firms, there is a sizable disparity in the number of clients served ranging from only one to several hundred clients. Yet, the majority of firms explicitly list employee benefit plan audits as a potential client service on their website. Finally, most public accounting firms in the sample have multiple partners but only operate a single office location. 
Table 3 provides univariate correlation statistics with Pearson correlations above the diagonal and Spearman correlations below the diagonal. Bolded coefficients represent those correlations that are statistically significant at the $1 \%$ level. Among the key independent variables, there is univariate support for each of the first three hypotheses. First, there is a negative correlation between LogAuditCount and Deficiency, consistent with industry knowledge that employee benefit auditors performing more audits have higher audit quality. Second, EBP_Industry_Website is negatively correlated with Deficiency, providing initial univariate support for the second hypothesis that firms signaling greater reputation have higher audit quality. Third, there is a positive correlation between ReviewerEBPCommitteeMember and Deficiency, providing initial univariate support for the third hypothesis. In other words, firms with a mismatch in industry status (i.e. preparer has "low" status but independent evaluator has "high" status in the employee benefit plan industry) are associated with an increased likelihood of receiving a deficiency in their peer review.

Within the key independent variables, public accounting firms with a larger number of employee benefit plan audits are more likely to list this service for potential clients on their website. These firms performing more audits also are more likely to have "high" status in the industry through employees on key industry committees. One item of note is that LogAuditCount is highly correlated with the primary size and firm sophistication control: LogPartners. In untabulated analyses, excluding LogPartners does not change the direction of the main results but in fact strengthens the statistical significance of the main regression analyses.

Finally, given the relatively small number of high status public accounting firms in the study's sample, there is a positive correlation between ReviewerEBPCommitteeMember and BothEBPCommitteeMember. This suggests that public accounting firms which have high status 
are more likely to hire a peer reviewer with a similar high status, similar to relationship existing in other professional service firms including investment bank underwriting (Podolny 1994).

\section{EMPIRICAL RESULTS}

\section{Determinants of Peer Review Report Deficiencies}

In the first three hypotheses of this study, it is predicted that public accounting firms with greater experience, greater reputation, and a less prominent mismatch in status with their peer reviewer will be less likely to receive deficiencies in their peer review. As described in equation 1, a logistic regression model is used to evaluate the effect of potential determinants on receiving a deficiency in their peer review (whether or not they "fail" the peer review or receive a "pass with deficiencies" grade). Table 4 provides the results of this analysis. Given that there is univariate evidence that firms with greater experience also potentially have a better reputation as well as higher status in their industry, each hypothesis is tested individually as well as within the full model to disentangle the relative effect of each of these potential determinants of audit quality. Evaluating each of the individual hypothesis tests, there is statistical support for each of the three hypotheses.

For the first hypothesis, public accounting firms auditing more clients (LogAuditCount) are less likely to receive a peer review deficiency $\left(\mathrm{X}^{2}=7.36\right)$, providing support for hypothesis 1 . Within the full model, there is still marginal statistical significance for LogAuditCount $\left(\mathrm{X}^{2}=3.06\right)$, suggesting that while this is not the primary driver of passing a peer review, it is nonetheless consistent with industry knowledge that auditing more clients allows for greater experience in dealing with compliance issues specific to this industry (DOL 2015). 
For the second hypothesis, public accounting firms which signal their reputation in the industry using their firm website are less likely to receive a peer review deficiency $\left(\mathrm{X}^{2}=6.58\right)$, providing support for hypothesis 2 . Within the full model, there is still marginal statistical significance for EBP_Industry_Website $\left(\mathrm{X}^{2}=3.21\right)$, suggesting that while this is not the primary driver of passing a peer review, signaling is still useful for potential clients to better identify their experience in the industry. In an untabulated regression, incorporating an interaction between LogAuditCount and EBP_Industry_Website into the main model provides a statistically significant negative association with receiving a peer review deficiency $\left(X^{2}=3.86, p=0.049\right)$. Thus suggests that public accounting firms may be more willing to signal their industry background if this industry makes up a larger proportion of their client mix (i.e. they perform more audits).

For the third hypothesis, the strongest empirical support is found related to the relative mismatch in industry status. Within the hypothesis 3 test including only these key independent variables, there is a positive and statistically significant association between ReviewerEBPCommitteeMember and the presence of a peer review deficiency $\left(\mathrm{X}^{2}=11.45\right)$. This result persists in the full model $\left(\mathrm{X}^{2}=9.29\right)$, providing strong support for hypothesis 3 .

This suggests that it is not the status of the public accounting firm performing the employee benefit plan engagement that matters but rather the social status of the independent evaluator. To providing additional evidence that this explanation may be correct, a pair of chisquared tests are performed. In the first test shown at the bottom of table 4 , there is no difference in the likelihood of a peer review deficiency between high status firms which use a "high" status independent evaluator or use a "low" status independent evaluator $\left(X^{2}=0.95, p=0.33\right)$. In the second test shown at the bottom of table 4 , there is no difference in the likelihood of a peer 
review deficiency between independent evaluators who are reviewing a "high" status public accounting firm or a "low" status public accounting firm $\left(\mathrm{X}^{2}=0.75, \mathrm{p}=0.39\right)$. Additionally, when splitting the sample by ReviewerEBPCommittee, there is no association between the status of a public accounting firm and peer review deficiencies in either subsample.

Taken together, there is support for each of the first three hypotheses. This study finds evidence that the most important factor in peer review deficiency is the status (and likely ability) of the independent evaluator, possibly due to the independent evaluator's investment in the industry and desire to retain their relative status therein (Fogarty 1996). Interestingly, this result does not appear to be the same as within the financial accounting peer review literature. When controlling for the potential competitive nature of the independent evaluator using NYPeerReviewer (Hilary and Lennox 2005; Anantharaman 2012) and whether the public accounting firm has independent evaluation experience performing peer reviews using AlsoReviewsEBPAQC (Anantharaman 2012), neither of these factors is statistically significant for this employee benefit plan sample. One potential explanation for this result is that the employee benefit plan industry is highly regulated and there may be greater switching costs involved in this industry.

\section{Role of Peer Review Deficiencies in Audit Changes}

While peer review deficiencies are an indicator of audit quality issues, changes in a public accounting firm's client portfolio capture whether their clients believe that audit quality issues are meaningful. The fourth hypothesis test whether public accounting firms that receive a deficiency in their peer review report are associated with a difference in their proportion of clients relative to those with a clean peer review report. 
Reviewing table 5 , under none of the specifications is there a statistically significant association between Deficiency and the change in client count dependent variables, rejecting hypothesis 4 . This suggests that either clients do not take into account the nature of the peer review report when evaluating their external auditor or that clients believe that general quality control structures are more critical to gaining client market share. Among the control variables, there is marginal support for both auditor reputation and status having an association with increased client market share. However, the strongest result is that there is a negative association between Zero_Issuers and changes in client market share. Assuming that public accounting firms which do not have a publicly traded client (Zero_Issuers $=1)$ do not have the same external pressure to enact better quality control processes, it is feasible that clients may be concerned that their audit performance will be substandard. This explanation is consistent with prior research that suggests that the PCAOB inspection process is more detailed in nature and improves audit quality (Westermann et al. 2018).

\section{ADDITIONAL ANALYSIS}

\section{Severe Instances of Peer Review Report Deficiencies}

While there was no association between the presence of a deficiency and changes in the audit client mix found in table 5, it is possible that clients may ignore instances of a non-clean peer review report opinion where the public accounting firm still receiving a passing grade. As noted in AICPA (2018), a failing grade indicates that the public accounting firm's system of quality control is "not suitably designed". If the peer review report information is informative to clients, it is likely that such a failing grade would be valuable information. In untabulated regressions, Deficiency is replaced with an indicator variable for a failing grade on their peer review and there is still no statistically significant association with a change in client mix. This 
suggests that, unlike in the financial accounting context, peer review reports are not valuable information for auditor selection.

\section{General Audit Firm Status Metric and Peer Review Outcomes}

Within this study, there is an assumption that the reputation and status of the public accounting firm in the employee benefit plan is independent of their firm size. However, it is feasible that independent evaluators and clients may pay less attention to industry-specific reputation and status and focus instead upon overall firm measures. In order to test this potential alternative explanation, the reputation variable (EBP_Industry_Website) and status variables (EBPCommitteeMember; ReviewerEBPCommitteeMember; BothEBPCommitteeMember) are replaced with variables measuring whether the public accounting firm (AT_Ranked) and the peer reviewer (ReviewerAT_Ranked) are listed in the Accounting Today “Top 100 Firms" national or regional list of largest firms by total revenue. For the peer review report deficiency test, the ranking from the calendar was used (e.g. peer review beginning during calendar year 2015, the 2014 Accounting Today rankings) to identify whether the public accounting firm or its independent evaluator were included in the relevant listing.

In an untabulated regression replicating the main test of determinants of peer review report deficiencies, there is no statistically significant association between the general status measures and the presence of peer review findings. Additionally, there is no association between the general status measures and changes in employee benefit plan client counts. This suggests that it is more appropriate to measure reputation and status using an industry-specific metric. 


\section{CONCLUSION}

Building upon prior research on peer review (e.g. Hilary and Lennox 2005; Casterella et al. 2009; Anantharaman 2012) and employee benefit plan audits (e.g. Cullinan 1997; Cullinan 1998; Arnold et al. 2016; Porter 2018), this study considers whether there is an association between audit firm reputation and status and peer review outcomes. This fills a gap in the literature considering audit quality in the regulated employee benefit plan industry.

Based upon the empirical analyses herein, there is evidence of an association between audit firm reputation and a reduction in the probability of receiving peer review deficiency. This suggests that signaling of expertise by a public accounting firm, or at least competence, at performing employee benefit plan audits is a meaningful signal. Additionally, this study provides evidence that public accounting firms performing independent evaluation service that have "high" status are more likely to identify deficiencies in peer review. While receiving a deficient peer review may be troublesome, this study does not find a link to changes in client counts. This suggests that public accounting firms should consider seeking out "high" status peer reviewers, whatever their own status in the industry, to ensure that they have the highest possible quality control structures in place.

From a public interest perspective, these findings suggest that regulation requiring employee benefit plan auditors to perform a minimum number of benefit plan audit engagements would enhance audit quality in this industry. While the AICPA recently adopted more stringent requirements for benefit plan audits under AICPA SAS 136 (AICPA 2019), more stringent standards will not enhance quality without a corresponding change in either the ability to participate in this audit market or a modification in the stringency of enforcement of audit standards during a system review. While there has been a push by the U.S. Department of Labor 
to establish accounting principles and auditing standards for this industry (DOL 2015), such an endeavor would only be effective with a corresponding increase in oversight over either market participation or the enforcement of quality control processes for employee benefit plan audits. While an explicit ban on public accounting firms only performing one or two employee benefit plan audit engagements would likely eliminate the firms with the poorest audit quality (DOL 2015), this would be relatively difficult to implement as DOL data, including that used in this study, is not available until almost a year after their audit completion date. More realistic is an increase in the stringency of audit regulation and enforcement under the purview of a government regulator akin to the PCAOB oversight of the financial statement audit sector.

Similar to other empirical studies, this study is subject to several limitations. First, unlike Casterella et al. (2009) which analyzes proprietary audit quality data, it is impossible to distinguish whether a clean peer review is due to the presence of high quality control structures or from a less stringent peer review (Board 2002). While this study controls for determinants identified in prior research that are expected to be associated with audit quality, further research may be able to better disentangle this information. Second, this study focuses upon a single state immediately following a transition in the peer review regulatory environment. While it is expected that public accounting firms would be particularly sensitive to implementing better quality control structures in this setting, the results may not generalize across the United States. Finally, the study focuses upon the highly regulated employee benefit plan industry. Given the stream of prior research in financial accounting peer review, these results do not necessarily suggest that private company peer review findings follow a similar pattern.

This study may benefit IRS and U.S. Department of Labor regulators in two ways. First, consistent with discussion in the 2014 employee benefit plan study of audit working papers 
(DOL 2015), there is evidence that firms which specialize in employee benefit plan audits have lower deficiency rates. While it remains unclear whether this extends to analysis of the full working papers as performed periodically by the U.S. Department of Labor, using this measure of industry reputation would allow for more detailed analysis of firm "specialization". Second, given that relative industry status may be associated with peer review outcomes, providing researchers with increased access to peer review reports of public accounting firms outside the AICPA Employee Benefit Plan Audit Quality Center could enhance the value proposition of a public accounting firm joining an AICPA quality center. This could serve as an important incremental step to increase audit quality in the employee benefit plan sector. 


\section{REFERENCES}

(CAQ), C. f. A. Q. Governing Board 2018 [cited 08/30/2018. Available from https://www.thecaq.org/governing-board.

AICPA. 2015. Practice Aid Series: Establishing and Maintaining a System of Quality Control for a CPA Form's Accounting and Auditing Practice. Available at: https://www.aicpa.org/interestareas/frc/enhancingauditqualitypracticeaid.html

. 2019. Statement of Auditing Standards No. 136: Forming an Opinion on Financial Statements of Employee Benefit Plans Subject to ERISA. Available at: https://www.aicpa.org/content/dam/aicpa/research/standards/auditattest/downloadabledoc uments/sas-136.pdf

Amir, E., and A. Ziv. 1997. Recognition, disclosure, or delay: Timing the adoption of SFAS No. 106. Journal of Accounting Research 35 (1):61-81.

Anantharaman, D. 2012. Comparing self-regulation and statutory regulation: Evidence from the accounting profession. Accounting, Organizations and Society 37 (2):55-77. 2017. The role of specialists in financial reporting: Evidence from pension accounting. Review of Accounting Studies 22 (3):1261-1306.

Ariely, D., A. Bracha, and S. Meier. 2009. Doing good or doing well? Image motivation and monetary incentives in behaving prosocially. American economic review 99 (1):544-555.

Arnold, B., H. Bateman, A. Ferguson, and A. Raftery. 2016. Partner-Scale Economies, Service Bundling, and Auditor Independence in the Australian Self-Managed Superannuation (Pension) Fund Industry. Auditing: A Journal of Practice \& Theory 36 (2):161-180.

Asthana, S. 1999. Determinants of funding strategies and actuarial choices for defined-benefit pension plans. Contemporary Accounting Research 16 (1):39-74.

Beaudoin, C., N. Chandar, and E. M. Werner. 2010. Are potential effects of SFAS 158 associated with firms' decisions to freeze their defined benefit pension plans? Review of Accounting and Finance 9 (4):424-451.

Bénabou, R., and J. Tirole. 2006. Incentives and prosocial behavior. American economic review 96 (5):1652-1678.

Bills, K. L., L. M. Cunningham, and L. A. Myers. 2015. Small audit firm membership in associations, networks, and alliances: Implications for audit quality and audit fees. The Accounting Review 91 (3):767-792.

Board, P. O. 2002. Final annual report 2001. Stamford Connecticut: Public Oversight Board.

Bodie, Z., A. J. Marcus, and R. C. Merton. 1988. Defined benefit versus defined contribution pension plans: What are the real trade-offs? In Pensions in the US Economy: University of Chicago Press, 139-162.

Carpenter, J., and C. K. Myers. 2010. Why volunteer? Evidence on the role of altruism, image, and incentives. Journal of Public Economics 94 (11-12):911-920.

Carson, E. 2009. Industry specialization by global audit firm networks. The Accounting Review 84 (2):355-382.

Casterella, J. R., K. L. Jensen, and W. R. Knechel. 2009. Is self-regulated peer review effective at signaling audit quality? The Accounting Review 84 (3):713-735.

Choy, H., J. Lin, and M. S. Officer. 2014. Does freezing a defined benefit pension plan affect firm risk? Journal of accounting and economics 57 (1):1-21.

Cullinan, C. P. 1997. Audit pricing in the pension plan audit market. Accounting and Business Research 27 (2):91-98. 
. 1998. Evidence of non-Big 6 market specialization and pricing power in a niche assurance service market. Auditing 17:47-57.

D'Souza, J., J. Jacob, and K. Ramesh. 2000. The use of accounting flexibility to reduce labor renegotiation costs and manage earnings. Journal of accounting and economics 30 (2):187-208.

DeFond, M. L. 2010. How should the auditors be audited? Comparing the PCAOB inspections with the AICPA peer reviews. Journal of accounting and economics 49 (1-2):104-108.

Dhaliwal, D. S. 1986. Measurement of financial leverage in the presence of unfunded pension obligations. The Accounting Review 61 (4):651-661.

DOL, U. S. 2015. Assessing the Quality of Employee Benefit Plans, edited by E. B. S. A. Office of the Chief Accountant. Washington D.C.

Finn, D. W., L. B. Chonko, and S. D. Hunt. 1988. Ethical problems in public accounting: The view from the top. Journal of Business Ethics 7 (8):605-615.

Fogarty, T. J. 1996. The imagery and reality of peer review in the US: Insights from institutional theory. Accounting, Organizations and Society 21 (2-3):243-267.

Francis, J. R. 2011. A framework for understanding and researching audit quality. Auditing: A Journal of Practice \& Theory 30 (2):125-152.

Francis, J. R., and S. A. Reiter. 1987. Determinants of corporate pension funding strategy. Journal of accounting and economics 9 (1):35-59.

Granovetter, M. 1983. The strength of weak ties: A network theory revisited. Sociological theory 1:201-233.

Grumet, L. 2005. Peer review: dealing with the reality of perceptions. The CPA Journal 75 (9):7.

Harper, M., and S. Allen. 1997. Volunteer to enhance your career and the profession. Journal of Accountancy 183 (2):41.

Hilary, G., and C. Lennox. 2005. The credibility of self-regulation: Evidence from the accounting profession's peer review program. Journal of accounting and economics 40 (1-3):211-229.

Kang, F., M. Farag, R. Hurt, and C. Wyrick. 2014. The association between PCAOB-identified audit deficiencies and small audit firms' characteristics: Evidence from PCAOB inspection reports. Managerial Auditing Journal 29 (8):717-735.

Knechel, W. R., G. V. Krishnan, M. Pevzner, L. B. Shefchik, and U. K. Velury. 2012. Audit quality: Insights from the academic literature. Auditing: A Journal of Practice \& Theory 32 (sp1):385-421.

Kranacher, M.-J. 2012. Protecting the Public from Fraud and Ensuring Audit Quality. The CPA Journal 82 (6): 17.

Lampe, J. C., A. Garcia, and K. L. Tassin. 2016. A Post-SOX History of US Public Accountancy. The History of Deprofessionalization in US Public Accountancy: Part III. In Research on Professional Responsibility and Ethics in Accounting: Emerald Group Publishing Limited, 3-29.

Lennox, C., and J. Pittman. 2010. Auditing the auditors: Evidence on the recent reforms to the external monitoring of audit firms. Journal of accounting and economics 49 (1-2):84103.

Libby, R., and J. Luft. 1993. Determinants of judgment performance in accounting settings: Ability, knowledge, motivation, and environment. Accounting, Organizations and Society $18(5): 425-450$. 
Löhlein, L. 2016. From peer review to PCAOB inspections: Regulating for audit quality in the US. Journal of Accounting Literature 36:28-47.

Moroney, R. 2007. Does industry expertise improve the efficiency of audit judgment? Auditing: A Journal of Practice \& Theory 26 (2):69-94.

Moroney, R., and P. Carey. 2011. Industry-versus task-based experience and auditor performance. Auditing: A Journal of Practice \& Theory 30 (2):1-18.

Moroney, R., and R. Simnett. 2009. Differences in industry specialist knowledge and business risk identification and evaluation. Behavioral Research in Accounting 21 (2):73-89.

O'Bannon, I. M. 11 Steps for a More Effective Accounting Firm Website 2016 [cited 08/28/2018. Available at: https://www.cpapracticeadvisor.com/news/12196287/11-steps-for-a-moreeffective-accounting-firm-website.

PCAOB. 2018. System of Quality Control for a CPA Firm's Accounting and Auditing Practice.

Pentland, B. T., and P. Carlile. 1996. Audit the taxpayer, not the return: Tax auditing as an expression game. Accounting, Organizations and Society 21 (2-3):269-287.

Podolny, J. M. 1994. Market uncertainty and the social character of economic exchange. Administrative science quarterly 39 (3):458-483.

Porter, C. M. 2018. Employee Benefit Plan Audits: The Current State and Future Direction. Current Issues in Auditing (In-Press).

Power, M. K. 2003. Auditing and the production of legitimacy. Accounting, Organizations and Society 28 (4):379-394.

Russell, J., and J. Armitage. 2006. Peer Review effectiveness: An analysis of potential loopholes within the USA Peer Review Program. Managerial Auditing Journal 21 (1):46-62.

Ryan, D. 2016. Understanding digital marketing: marketing strategies for engaging the digital generation: Kogan Page Publishers.

Sellers, R. D., T. J. Fogarty, and L. M. Parker. 2015. The Center Cannot Hold: The AICPA and Accounting Professional Leadership 1997-2013. Accounting Horizons 29 (3):485-506.

Suddaby, R., G. D. Saxton, and S. Gunz. 2015. Twittering change: The institutional work of domain change in accounting expertise. Accounting, Organizations and Society 45:52-68.

Tysiac, K. 2015. Succeeding with a narrow focus. Journal of Accountancy 220 (3):56.

Weigelt, K., and C. Camerer. 1988. Reputation and corporate strategy: A review of recent theory and applications. Strategic management journal 9 (5):443-454.

Westermann, K. D., J. Cohen, and G. Trompeter. 2018. PCAOB inspections: Public accounting firms on "trial". Contemporary Accounting Research (In-Press). 


\section{APPENDIX A}

\section{Variable Definitions}

\section{Panel A: Dependent Variables}

\begin{tabular}{|c|c|c|}
\hline$\underline{\text { Variable }}$ & Variable Definition & Data Source \\
\hline Deficiency & $\begin{array}{l}\text { Indicator variable, } \\
1=\text { deficiency identified in peer review report, } 0=\text { otherwise }\end{array}$ & $\begin{array}{l}\text { AICPA Peer Review } \\
\text { Public File }\end{array}$ \\
\hline Log (Chg. In EBP clients) & $\begin{array}{l}\text { Natural log of the change in the number of employee benefit } \\
\text { plan clients which are not due to client plan } \\
\text { closures/openings }\end{array}$ & $\begin{array}{l}\text { U.S. Department of Labor } \\
\text { Form } 5500 \text { data }\end{array}$ \\
\hline$\%$ Chg in EBP clients & $\begin{array}{l}\text { Percentage change in the number of employee benefit plan } \\
\text { clients which are not due to client plan closures/openings }\end{array}$ & $\begin{array}{l}\text { U.S. Department of Labor } \\
\text { Form } 5500 \text { data }\end{array}$ \\
\hline Sign (Chg in EBP clients) & $\begin{array}{l}\text { Indicator variable, } \\
1=\text { increase in the number of employee benefit plan clients } \\
\text { which are not due to client plan closures/openings, } \\
0=\text { no change in client count as described above, } \\
-1=\text { decrease in client count as described above }\end{array}$ & $\begin{array}{l}\text { U.S. Department of Labor } \\
\text { Form } 5500 \text { data }\end{array}$ \\
\hline
\end{tabular}

\section{Panel B: Key Independent Variables}

\begin{tabular}{|l|l|l|}
\hline Variable & Variable Definition & Data Source \\
\hline LogAuditCount & $\begin{array}{l}\text { Natural log of the number of audit clients for the matched } \\
\text { year which the peer review takes place }\end{array}$ & $\begin{array}{l}\text { U.S. Department of Labor } \\
\text { Form 5500 data }\end{array}$ \\
\hline EBP_Industry_Website & $\begin{array}{l}\text { Indicator variable, } \\
1=\text { firm lists employee benefit plan audits as a professional } \\
\text { service on their website, } 0=\text { otherwise }\end{array}$ & Hand Collected \\
\hline EBPCommitteeMember & $\begin{array}{l}\text { Indicator variable, } \\
1=\text { firm has an employee on either the AICPA or NY state } \\
\text { society of CPAs employee benefit plan committee as of } \\
\text { November 2017, } \\
0=\text { otherwise }\end{array}$ & Hand Collected \\
\hline $\begin{array}{l}\text { ReviewerEBPCommittee } \\
\text { Member }\end{array}$ & $\begin{array}{l}\text { Indicator variable, } \\
1=\text { firm's independent evaluator has an employee on any of } \\
\text { the AICPA, the NY state society of CPAs, or their own } \\
\text { state's employee benefit plan committees as of November } \\
2017,0=\text { otherwise }\end{array}$ & Hand Collected \\
\hline $\begin{array}{l}\text { BothEBPCommittee } \\
\text { Member }\end{array}$ & $\begin{array}{l}\text { Indicator variable, } \\
1=\text { both EBPCommitteeMember and } \\
\text { ReviewerEBPCommitteeMember equal one, } 0=\text { otherwise }\end{array}$ & Hand Collected \\
\hline
\end{tabular}




\section{APPENDIX A (continued)}

\section{Variable Definitions}

\section{Panel C: Control Variables}

\begin{tabular}{|c|c|c|}
\hline Variable & Variable Definition & Data Source \\
\hline NYPeerReviewer & $\begin{array}{l}\text { Indicator variable, } \\
1=\text { firm's independent evaluator is headquartered in New } \\
\text { York state, } \\
0=\text { otherwise }\end{array}$ & Hand Collected \\
\hline AlsoReviewsEBPAQC & $\begin{array}{l}\text { Indicator variable, } \\
1=\text { firm performs peer review services as an independent } \\
\text { evaluator for other public accounting firms, } 0=\text { otherwise }\end{array}$ & $\begin{array}{l}\text { AICPA Peer Review Reviewer } \\
\text { Data File }\end{array}$ \\
\hline LogPartners & $\begin{array}{l}\text { Natural log of the number of partners in the public } \\
\text { accounting firm }\end{array}$ & Hand Collected \\
\hline $\begin{array}{l}\text { Human_Capital_- } \\
\text { Leverage Ratio }\end{array}$ & $\begin{array}{l}\text { Ratio of the total number of CPAs relative to the number of } \\
\text { audit partners in the public accounting firm }\end{array}$ & Hand Collected \\
\hline Zero_Issuers & $\begin{array}{l}\text { Indicator variable, } \\
1=\text { firm does not perform any audits of publicly traded } \\
\text { companies in the matched year, } 0=\text { otherwise }\end{array}$ & $\begin{array}{l}\text { PCAOB Firm Database and } \\
\text { Audit Analytics }\end{array}$ \\
\hline SoleProprietorship & $\begin{array}{l}\text { Indicator variable, } \\
1=\text { firm has only one audit partner, } 0=\text { otherwise }\end{array}$ & Hand Collected \\
\hline SingleOffice & $\begin{array}{l}\text { Indicator variable, } \\
1=\text { firm has more than one audit partner with only one office } \\
\text { location, } 0=\text { otherwise }\end{array}$ & Hand Collected \\
\hline LogPreAuditCount & $\begin{array}{l}\text { Natural log of the number of audit clients for the } 1 \text { year prior } \\
\text { to the start of the peer review }\end{array}$ & $\begin{array}{l}\text { U.S. Department of Labor } \\
\text { Form } 5500 \text { data }\end{array}$ \\
\hline
\end{tabular}


TABLE 1

Sample Composition

Panel A: Calculation of Sample Size

\section{Description}

New York registered public accounting firms with:

(1) Membership in AICPA Employee Benefit Plan Quality Center

$\underline{\mathbf{N}}$

(2) Publicly available peer review report information

Less: Firms under PCAOB annual inspection

175

Less: Firms which are subsequently acquired

Less: Firms without a company website

Less: Firms with partner count missing from website

Less: Firms with missing identity of independent evaluator for peer review

Less: Firms with missing Department of Labor Form 5500 information

Total firm observations for testing hypotheses 1 -3

Less: Firms with missing subsequent year Form 5500 data

(i.e. peer review completed in 2017 or 2018)

Less: Firms with no employee benefit plan audits in the year prior to the peer

review in the Form 5500 data

Total firm observations for testing hypothes is 4

99

Panel B: Relative Distribution of Peer Review Report Outcomes in Sample Data

\begin{tabular}{|c|c|c|c|c|c|}
\hline & \multicolumn{4}{|c|}{$\underline{\text { Peer Review Outcome }}$} & \multirow[b]{2}{*}{$\%$ Pass } \\
\hline & $\underline{\text { Pass }}$ & $\frac{\text { Pass with }}{\text { Deficiencies }}$ & Fail & $\underline{\text { Total }}$ & \\
\hline Full Sample & 144 & 21 & 10 & 175 & $82.3 \%$ \\
\hline Tests of H1 - H3 & 118 & 17 & 4 & 139 & $84.9 \%$ \\
\hline Test of H4 & 83 & 14 & 2 & 99 & $83.8 \%$ \\
\hline
\end{tabular}


TABLE 2

Descriptive Statistics

\begin{tabular}{|l|c|c|c|c|c|c|}
\hline Variable & N & Min & Mean & Median & Max & Std Dev \\
\hline Log (Chg. In EBP clients) & 97 & -5.98 & -0.24 & 0 & 4.88 & 2.88 \\
\hline$\%$ Chg in EBP clients & 97 & -0.06 & -0.06 & 0 & 1.90 & 0.90 \\
\hline Sign (Chg in EBP clients) & 97 & -1 & -0.04 & 0 & 1 & 0.98 \\
\hline Deficiency & 139 & 0 & 0.16 & 0 & 1 & 0.37 \\
\hline LogAuditCount & 139 & 0 & 2.43 & 2.40 & 6.64 & 1.52 \\
\hline EBP_Industry_Website & 139 & 0 & 0.71 & 1 & 1 & 0.45 \\
\hline EBPCommitteeMember & 139 & 0 & 0.11 & 0 & 1 & 0.31 \\
\hline ReviewerEBPCommitteeMember & 139 & 0 & 0.19 & 0 & 1 & 0.39 \\
\hline BothEBPCommitteeMember & 139 & 0 & 0.04 & 0 & 1 & 0.19 \\
\hline NYPeerReviewer & 139 & 0 & 0.65 & 1 & 1 & 0.48 \\
\hline AlsoReviewsEBPAQC & 139 & 0 & 0.23 & 0 & 1 & 0.42 \\
\hline LogPartners & 139 & 0 & 1.81 & 1.79 & 4.43 & 1.03 \\
\hline Human_Capital_Leverage_Ratio & 139 & 0.75 & 1.63 & 1.40 & 7.43 & 0.88 \\
\hline Zero_Issuers & 139 & 0 & 0.83 & 1 & 1 & 0.37 \\
\hline SoleProprietorship & 139 & 0 & 0.06 & 0 & 1 & 0.23 \\
\hline SingleOffice & 139 & 0 & 0.55 & 1 & 1 & 0.50 \\
\hline LogPreAuditCount & 97 & 0 & 2.52 & 2.40 & 6.60 & 1.41 \\
\hline \hline
\end{tabular}


TABLE 3

\section{Univariate Correlations}

\begin{tabular}{|c|c|c|c|c|c|c|c|c|c|c|c|c|c|c|}
\hline$\underline{\text { Variable }}$ & & $\underline{1}$ & $\underline{2}$ & $\underline{3}$ & $\underline{4}$ & $\underline{5}$ & $\underline{6}$ & $\underline{7}$ & $\underline{8}$ & $\underline{9}$ & $\underline{10}$ & $\underline{11}$ & $\underline{12}$ & $\underline{13}$ \\
\hline 1 & Deficiency & & -0.30 & -0.33 & -0.02 & 0.45 & 0.02 & 0.11 & -0.24 & -0.17 & -0.10 & 0.09 & -0.02 & 0.08 \\
\hline 2 & LogAuditCount & -0.30 & & 0.43 & 0.27 & -0.10 & 0.09 & -0.40 & 0.20 & 0.61 & -0.03 & -0.48 & -0.13 & -0.22 \\
\hline 3 & EBP_Industry_Website & -0.33 & 0.44 & & 0.17 & -0.10 & 0.12 & -0.19 & 0.16 & 0.24 & 0.00 & -0.15 & 0.09 & -0.04 \\
\hline 4 & EBPCommitteeMember & -0.02 & 0.28 & 0.17 & & 0.13 & 0.56 & -0.19 & 0.09 & 0.24 & -0.11 & -0.22 & 0.11 & -0.24 \\
\hline 5 & $\begin{array}{l}\text { Reviewer } \\
\text { EBPCommitteeMember }\end{array}$ & 0.45 & -0.09 & -0.10 & 0.13 & & 0.40 & 0.15 & -0.13 & -0.12 & -0.08 & 0.02 & 0.12 & -0.01 \\
\hline 7 & NYPeerReviewer & 0.11 & -0.40 & -0.19 & -0.19 & 0.15 & 0.06 & & -0.18 & -0.44 & 0.00 & 0.45 & 0.11 & 0.13 \\
\hline 8 & AlsoReviewsEBPAQC & -0.24 & 0.19 & 0.16 & 0.09 & -0.13 & 0.08 & -0.18 & & 0.34 & 0.12 & -0.12 & -0.14 & -0.15 \\
\hline 9 & LogPartners & -0.17 & 0.58 & 0.24 & 0.18 & -0.12 & 0.07 & -0.43 & 0.31 & & -0.15 & -0.52 & -0.43 & -0.25 \\
\hline 10 & $\begin{array}{l}\text { Human_Capital } \\
\text { Leverage_Ratio }\end{array}$ & -0.12 & 0.00 & -0.02 & -0.11 & -0.10 & -0.09 & 0.05 & 0.20 & -0.08 & & 0.15 & -0.04 & 0.02 \\
\hline
\end{tabular}

Pearson correlations are included above the diagonal and Spearman correlations are included below the diagonal.

Bolded coefficients are statistically significant at the $1 \%$ level. 
TABLE 4

Logistic Regression of Determinants of Peer Review Deficiencies

\begin{tabular}{|c|c|c|c|c|c|c|c|c|c|c|c|}
\hline \multirow[b]{3}{*}{ Parameter } & \multirow[b]{3}{*}{ Pred. } & \multicolumn{10}{|c|}{ Dependent Variable $=$ Prob $($ Deficiency $=1)$} \\
\hline & & \multicolumn{2}{|c|}{$\underline{\text { H1 Test }}$} & \multicolumn{2}{|c|}{$\underline{\text { H2 Test }}$} & \multicolumn{3}{|c|}{$\underline{\text { H3 Test }}$} & \multicolumn{3}{|c|}{ Full Model } \\
\hline & & Est. & $\mathbf{X}^{2}$ & Est. & $\mathbf{X}^{2}$ & Est. & $\mathbf{X}^{2}$ & & Est. & $\mathbf{X}^{2}$ & \\
\hline Intercept & & -7.50 & 0.00 & -8.71 & 0.00 & -8.78 & 0.00 & & -6.68 & 0.00 & \\
\hline \multicolumn{12}{|l|}{ Audit Firm Experience (H1) } \\
\hline LogAuditCount & - & -0.84 & $7.36 * * *$ & & & & & & -0.68 & 3.06 & $*$ \\
\hline \multicolumn{12}{|l|}{ Audit Firm Reputation (H2) } \\
\hline EBP_Industry_Website & - & & & -1.59 & 6.58 & $* *$ & & & -1.55 & 3.21 & $*$ \\
\hline \multicolumn{12}{|l|}{ Audit Firm Status (H3) } \\
\hline EBPCommitteeMember & - & & & & & 1.18 & 0.69 & & 2.15 & 1.63 & \\
\hline ReviewerEBPCommitteeMember & + & & & & & 2.51 & 11.45 & $* * *$ & 2.57 & 9.29 & $* * *$ \\
\hline BothEBPCommitteeMembers & - & & & & & 1.11 & 0.24 & & -0.08 & 0.00 & \\
\hline \multicolumn{12}{|l|}{ Audit Firm Structure Controls } \\
\hline NYPeerReviewer & & 0.06 & 0.01 & -0.16 & 0.05 & -0.96 & 1.20 & & -0.33 & 0.12 & \\
\hline AlsoReviewsEBPAQC & & -19.43 & 0.17 & -19.57 & 0.17 & -24.23 & 0.37 & & -21.16 & 0.26 & \\
\hline LogPartners & & 0.05 & 0.01 & -0.48 & 0.97 & -1.23 & 3.77 & $*$ & -0.36 & 0.24 & \\
\hline Human_Capital_Leverage_Ratio & & -0.28 & 0.34 & -0.15 & 0.12 & -0.35 & 0.51 & & -0.16 & 0.07 & \\
\hline Zero_Issuers & & -0.26 & 0.07 & 0.20 & 0.04 & 0.44 & 0.19 & & 0.09 & 0.01 & \\
\hline SoleProprietorship & & -7.41 & 0.09 & -6.80 & 0.08 & -10.68 & 0.30 & & -7.39 & 0.13 & \\
\hline SingleOffice & & -0.33 & 0.20 & -0.05 & 0.01 & -0.11 & 0.02 & & 0.04 & 0.00 & \\
\hline Year Controls & \multicolumn{3}{|c|}{ Included } & \multicolumn{2}{|l|}{ Included } & \multicolumn{2}{|l|}{ Included } & \multicolumn{3}{|c|}{ Included } & \\
\hline Number of Observations & \multicolumn{3}{|c|}{139} & \multicolumn{2}{|l|}{139} & \multicolumn{2}{|l|}{139} & \multicolumn{3}{|c|}{139} & \\
\hline Percent Concordant & \multicolumn{3}{|c|}{88.9} & \multicolumn{2}{|l|}{88.6} & \multicolumn{2}{|l|}{92.3} & \multicolumn{3}{|c|}{95.4} & \\
\hline Pseudo $\mathrm{R}^{2}$ & \multirow{2}{*}{\multicolumn{3}{|c|}{$\begin{array}{r}0.50 \\
73.81\end{array}$}} & \multicolumn{2}{|l|}{0.48} & \multicolumn{2}{|l|}{0.56} & \multicolumn{3}{|c|}{0.65} & \\
\hline \multirow[t]{2}{*}{-2 Log Likelihood } & & & & 76.05 & & 66.17 & & & 55.44 & & \\
\hline & & & & & & & & & $\underline{\text { Wald } X^{2}}$ & $\underline{\operatorname{Pr}>X^{2}}$ & \\
\hline \multirow{2}{*}{\multicolumn{9}{|c|}{ Test \#1: EBPCommitteeM ember $=($ EBPCommM ember + ReviewerEBPCommM ember + BothEBPCommM ember $)$}} & 0.95 & 0.33 & \\
\hline & & & & & & & & & 0.75 & 0.39 & \\
\hline
\end{tabular}

Variables are defined within Appendix A.

Coefficients are statistically significant at the $10 \%$ level $(*), 5 \%$ level $(* *)$, and $1 \%$ level $(* * *)$ as noted herein. 
TABLE 5

Regression Analysis of Determinants of Changes in Employee Benefit Plan Client Count

\begin{tabular}{|c|c|c|c|c|c|c|c|c|c|c|}
\hline \multirow[b]{2}{*}{ Parameter } & \multirow[b]{2}{*}{ Pred. } & \multicolumn{3}{|c|}{$\begin{array}{c}\text { DV = Log Chg. in } \\
\text { EBP Clients }\end{array}$} & \multicolumn{3}{|c|}{$\begin{array}{c}D V=\% \text { Chg. in } \\
\text { EBP Clients }\end{array}$} & \multicolumn{3}{|c|}{$\begin{array}{c}D V=\text { Sign (Chg. in } \\
\text { EBP Clients) }\end{array}$} \\
\hline & & Est. & t Value & & Est. & t Value & & Est. & t Value & \\
\hline Intercept & & 1.16 & 2.41 & $* *$ & 0.44 & 2.57 & $* *$ & & & \\
\hline Intercept $($ sign $=0)$ & & & & & & & & 1.70 & 2.34 & \\
\hline Intercept $(\operatorname{sign}=-1)$ & & & & & & & & 0.94 & 40.80 & $* * *$ \\
\hline \multicolumn{11}{|l|}{ Peer Review Report Outcome (H4) } \\
\hline Deficiency & - & 0.04 & 0.13 & & 0.10 & 0.87 & & 0.21 & 0.17 & \\
\hline \multicolumn{11}{|l|}{ Audit Firm Test Variables (H1-H3) } \\
\hline LogAuditCount & & 0.10 & 0.44 & & 0.06 & 0.66 & & 0.20 & 0.28 & \\
\hline EBP_Industry_Website & & 0.25 & 1.69 & $*$ & 0.05 & 1.01 & & 0.43 & 1.83 & \\
\hline EBPCommitteeMember & & -0.12 & -0.58 & & -0.02 & -0.57 & & -0.45 & 0.59 & \\
\hline ReviewerEBPCommitteeMember & & -0.11 & -0.37 & & -0.12 & -1.44 & & -0.18 & 0.16 & \\
\hline BothEBPCommitteeMembers & & 0.73 & 1.45 & & 0.33 & 1.99 & $* *$ & 0.62 & 0.43 & \\
\hline \multicolumn{11}{|l|}{ Audit Firm Structure Controls } \\
\hline NYPeerReviewer & & -0.23 & -1.35 & & -0.12 & -2.07 & $* *$ & -0.44 & 1.80 & \\
\hline AlsoReviewsEBPAQC & & 0.08 & 0.41 & & -0.03 & -0.70 & & 0.29 & 0.79 & \\
\hline LogPartners & & -0.06 & -0.71 & & -0.03 & -1.17 & & -0.23 & 1.29 & \\
\hline Human_Capital_Leverage_Ratio & & 0.08 & 0.77 & & 0.01 & 0.17 & & 0.03 & 0.03 & \\
\hline Zero_Issuers & & -0.79 & -4.01 & $* * *$ & -0.16 & -2.32 & $* *$ & -1.21 & 7.38 & $* * *$ \\
\hline SoleProprietorship & & 0.00 & 0.00 & & 0.05 & 0.28 & & -0.27 & 0.15 & \\
\hline SingleOffice & & -0.03 & -0.25 & & -0.02 & -0.66 & & -0.19 & 0.44 & \\
\hline PreLogAuditCount & & -0.22 & -1.01 & & -0.11 & -1.21 & & -0.28 & 0.52 & \\
\hline Year Controls & \multicolumn{4}{|c|}{ Included } & \multicolumn{3}{|c|}{ Included } & \multicolumn{3}{|c|}{ Included } \\
\hline Number of Observations & \multicolumn{4}{|c|}{99} & \multicolumn{3}{|l|}{99} & \multicolumn{3}{|c|}{99} \\
\hline Adjusted $\mathrm{R}^{2}$ & \multicolumn{4}{|c|}{0.110} & \multicolumn{3}{|l|}{0.085} & & & \\
\hline Root Mean Squared Error & \multirow{2}{*}{\multicolumn{4}{|c|}{0.707}} & \multirow{2}{*}{\multicolumn{3}{|c|}{0.228}} & & & \\
\hline -2 Log Likelihood & & & & & & & & 193.05 & & \\
\hline
\end{tabular}

Changes in client count capture the change in clients following Hilary and Lennox (2005). Other variables are defined within Appendix A.

Coefficients are statistically significant at the $10 \%$ level (*), 5\% level (**), and $1 \%$ level (***) as noted herein. 